\title{
The Ability of Soil Candida albicans Secreted Potential Protease and Lipase
}

Ririn Puspadewi, Putranti Adirestuti, Mira Andam Dewi, Wakilatul Hasanah

Universitas Jenderal Achmad Yani, Cimahi, West Java, Indonesia

Corresponding author: ririn.puspadewi@lecture.unjani.ac.id

\begin{abstract}
Candida spp secreted a different kind of extracellular enzymes. Protease and lipase are the enzymes that are commonly used in the food and pharmaceutical industries. This study aimed to examine protease and lipase activity of Candida tropicalis isolated from the soil of the Medicinal Plant Garden of the Faculty of Pharmacy, Universitas Jenderal Achmad Yani, Indonesia. Candida isolate was subjected to the fermentation process to obtain bioactive metabolites. The result was analyzed using ANOVA within a 5\% interval of confidence, continuing with PostHoc. The result showed the Candida tropicalis metabolite giving the best proteolytic index value $(0,6556 \pm 0,0090) \mathrm{U} / \mathrm{mL}$. The metabolite isolate of Candida tropicalis had the highest activity, amounting to $5,776 \pm 0,495 \mathrm{U} / \mathrm{mL}$. The best results of lipolytic index value $(0,394 \pm 0,053) \mathrm{U} / \mathrm{mL}$. The Candida tropicalis metabolites produced the highest lipase enzyme after nine days of fermentation in $5.2917 \pm 0,0167 \mathrm{U} / \mathrm{mL}$.
\end{abstract}

Keywords: Candida tropicalis; fermentation; protease; lipase.

\section{Introduction}

Microorganisms are the most widely used source of enzymes compared to plants and animals. As a source of enzymes, microbes are more beneficial because of their rapid growth and can grow on inexpensive substrates more easily. The results are improved by regulating growth conditions and genetic engineering (Oktavia et al., 2018). Enzymes are macromolecules that can increase the rate of a chemical reaction. Enzymes can act as regulators that cause various metabolic functions to be coordinated harmoniously. Besides serving as a metabolic system for living things, enzymes can also be widely used in various research and industry fields. They require low energy, are selective to specific substrates, are biocompatible, biodegradable, and are obtained from renewable sources (Y. Liu \& Chen, 2016). Extracellular enzymes produced by microbes are used to break down complex organic nutrient material to be transported into cells as a source of nutrition (Subagiyo et al., 2017).

Candida spp can produce various extracellular enzymes that are hydrolytic. The enzymes that are released can be virulent, giving rise to the pathogenesis of Candida. (Pandey et al., 2018; Zuza-Alves et al., 2017). Yeast can degrade polymers that cannot be absorbed by producing extracellular enzymes (Ramnath et al., 2017). Candida tropicalis is a type of yeast that can carry out two main processes in converting cellulose material into ethanol. The hydrolysis of cellulose degradation to glucose and fermentation of converting glucose into bioethanol (Hermansyah et al., 2016). Besides, Candida tropicalis 
is also widely analyzed in the production of xylitol. Candida tropicalis can convert xylose to xylitol, which is used as an antibacterial Streptococcus mutan (Mahyati, 2017).

Protease is an enzyme that can hydrolyze proteins into simpler compounds such as peptides and amino acids. Microbial proteinase has potential for detergents, leather, silver recovery, milk, baking, beverages, and the pharmaceutical industry. This hydrolytic enzyme is efficiently involved in the food industry. That increases the nutritional value, digestibility, palatability, and taste, reduces allergies and manages domestic and industrial waste (Soeka \& Sulistiani, 2017).

Lipase catalyzes the hydrolysis of fat in water and lipids' interface and carries various biotransformation reactions under low water conditions. Sources of lipases include microbial lipases, bacteria, and fungi (Gupta et al., 2015). Lipase is a hydrolytic enzyme widely used in industrial fields and potentially in the medical field (Bharathi et al., 2019). Microbial activity in lipid degradation is related to these microbes' ability to produce a lipase enzyme called lipolytic. Lipase is a soluble enzyme hydrolyzing triacylglycerol to free fatty acids and glycerol (Bestari \& Suharjono, 2015). Research related to Candida tropicalis activity of the enzyme is a phospholipase isolated from the blood of patients in the intensive care unit Research on Candida tropicalis isolated from the soil to produce the extracellular enzyme with the addition of nutrients to the fermentation substrate has not been available

Based on the description above, research has been carried out to determine the extracellular enzyme activity of Candida tropicalis isolates by optimizing the fermentation substrate to obtain metabolites.

\section{Material and Method}

In this study, we were using a sample of Candida tropicalis, which was successfully isolated from the soil of the Medicinal Plant Garden of the Faculty of Pharmacy, Universitas Jenderal Achmad Yani, Cimahi. A total of 5 grams of soil was immersed in 50 mL PDB media, then homogenized and incubated for three days. Microbes that grow on PDB media are separated by repeating cultures on PDA media by incubating for three days at $25^{\circ} \mathrm{C}$. The isolation results obtained several isolates. The cultivation results got one isolate with the same macroscopic characteristics every time it was cultivated on PDA media. The process was repeated until a single isolate was obtained. These single isolates are genotypically identified. Identification was carried out on a single isolate at LIPI Bogor. Identification of isolates was carried out molecularly based on genetic analysis of $26 \mathrm{~S}$ ribosomal DNA.

The fermentation is then performed using PDB media with an inoculum of $10 \% \mathrm{v} / \mathrm{v}$ of the fermentation media. Growth kinetics of isolates were analyzed by growing isolates in fermentation media with an incubation period of 14 days in an incubator at $30^{\circ} \mathrm{C}$ and shaking at $125 \mathrm{rpm}$ for 1-2 hours per day before measurement. Observations were made every 24 hours for 14 days by measuring the absorption at a wavelength of $640 \mathrm{~nm}$ (Weerasekera et al., 2016; A et al., 2017) 
The cultivation results are dissolved in a $\mathrm{NaCl}$ solution, and the transmittance is measured at $25 \%$ with a visible spectrophotometer at a wavelength of $640 \mathrm{~nm}$. A total of $10 \% \mathrm{v} / \mathrm{v}$ culture was inoculated on substrates containing different fermented nutrient compositions and subsequently incubated in an incubator at $30^{\circ} \mathrm{C}$ with a shaking speed of $125 \mathrm{rpm}$ for 1-2 hours on the 3rd, 5th, and 13th days of fermentation. The results were centrifuged at $4000 \mathrm{rpm}$ for 30 minutes. A supernatant is taken then tested the activity of the microbial test and enzyme potential test. The nutrients added to see its ability to help the growth of Candida tropicalis. Nutrient composition added to the fermentation substrate used as follows in Table 1:

Table 1. Nutritional composition of the fermented substrate

\begin{tabular}{clcccc}
\hline No & $\begin{array}{c}\text { Composition of } \\
\text { substrate }\end{array}$ & $\begin{array}{c}\mathbf{C} \\
\text { (g/100mL) }\end{array}$ & $\begin{array}{c}\text { T1 } \\
\text { (g/100mL) }\end{array}$ & $\begin{array}{c}\text { T2 } \\
\text { (g/100mL) }\end{array}$ & $\begin{array}{c}\text { T3 } \\
\text { (g/100mL) }\end{array}$ \\
\hline \multirow{2}{1}{1} & Potato Dextrose Broth & 2,4 & 2,4 & 2,4 & 2,4 \\
& $(\mathrm{PDB})$ & - & 1 & 1,5 & 2 \\
2 & $\mathrm{KH}_{2} \mathrm{PO}_{4}$ & - & 0,5 & 0,5 & 0,5 \\
3 & $\mathrm{MgSO}_{4}$ & \multicolumn{2}{c}{} \\
\hline
\end{tabular}

The protease test using the Biuret test using $1 \mathrm{~mL}$ supernatant metabolite Candida tropicalis isolates were taken and added $1 \mathrm{~mL}$ of $10 \%$ sodium hydroxide $(\mathrm{NaOH})$ solution to the test tube, stirring vigorously. Two drops of $0.1 \%$ Copper Sulfate (CuSO4) solution was added and mixed well. If no color arises, add a few drops of a solution of Copper Sulfate (CuSO4) to form a purple tint. The skim milk solution 1\%(containing protein) is used as a positive comparison biuret test (Liu \& Pan, 2017).

Proteolytic tests were performed using Skim Milk Agar (SMA) media, namely PDA media plus $2 \%$ skim milk. Media that has been perforated using a perforator. Supernatant metabolites of Candida tropicalis isolates were inoculated in the perforated media, then incubated for three days at $25^{\circ} \mathrm{C}$. The proteolytic activity of microorganisms grown on Skim Milk Agar (SMA) media is indicated by the visible area of the transparent area around the colony formed. Furthermore, the clear zones that appear are measured in diameter and calculated semi-quantitative to obtain a proteolytic (Duanis-Assaf et al., 2020). The test was carried out with four repetitions. The result was analyzed using analysis of variance (ANOVA) within a $5 \%$ interval of confidence, continue with PostHoc.

The proteolytic index can be calculated as follow.

DK: Diameter of the microorganism colony

$$
\text { Proteolytic Index }=\frac{\mathrm{DZ}-\mathrm{DK}}{\mathrm{DK}}
$$

DZ: Diameter of the clear zone

The protease test was carried out by adding $1 \mathrm{~mL}$ of the supernatant metabolite of Candida tropicalis isolate into $3 \mathrm{~mL}$ of $0.5 \%$ casein solution, then incubated at $37^{\circ} \mathrm{C}$ for 30 minutes. Enzyme activity was stopped by adding $5 \mathrm{~mL}$ of $5 \%$ solution of Trichloroacetic 
Acid (TCA), then incubated at room temperature for 30 minutes, then centrifuged for 30 minutes to obtain a supernatant. Protease activity was determined by measuring the fermented supernatant's absorption value using a UV-Visible spectrophotometer at a wavelength of $280 \mathrm{~nm}$ (Ozturkoglu-Budak et al., 2016).

Lipolytic tests were performed using Potato Dextrose Agar (PDA) containing 2.5\% Tween-80, 5\% pure olive oil, and $0.01 \%$ methyl red. Media that has been perforated using a perforator. Supernatant metabolites of Candida tropicalis isolates were inoculated in solid media, then incubated for three days at $25^{\circ} \mathrm{C}$. The lipolytic activity of microorganisms is shown by a yellowish-white area considered a clear zone that appears around the formed colonies. Furthermore, the clear zone is measured in diameter and calculated quantitatively to obtain the lipolytic index (Bestari \& Suharjono, 2015). The test was carried out with four repetitions. The result was analyzed using analysis of variance (ANOVA) within a 5\% interval of confidence, continue with PostHoc.

The lipolytic index can be calculated as follow.

DK: Diameter of the microorganism colony

$$
\text { Lipolytic index }=\frac{D Z-D K}{D K}
$$

DZ: Diameter of the clear zone

Lipase activity was measured quantitatively by $1 \mathrm{~mL}$ supernatant metabolite of Candida tropicalis isolates plus $1 \mathrm{ml}$ of sterile olive oil and $2 \mathrm{~mL}$ of phosphate buffer $\mathrm{pH}$ seven, then incubated at $40 \mathrm{oC}$ for 30 minutes. After incubation, $5 \mathrm{~mL}$ of acetone-ethanol (1: 1) solution is added and given two drops of phenolphthalein (PP) indicator then titrated with $0.05 \mathrm{~N}$ sodium hydroxide $(\mathrm{NaOH})$ until it starts to turn pale pink (Bestari \& Suharjono, 2015). The test was carried out with three repetitions.

Lipase activity can be calculated as follows.

A: Volume (mL) $\mathrm{NaOH}$ for sample titration

$$
\text { Lipase activity }(\mathrm{U} / \mathrm{mL})=\frac{(\mathrm{A}-\mathrm{B}) \times \mathrm{N} \mathrm{NaOH} \times 1000}{\mathrm{VE} \times 30}
$$

B: Volume $(\mathrm{mL}) \mathrm{NaOH}$ for blank titration

1000: Convert mmol to $\mu \mathrm{mol}$

30: incubation time

VE: Total supernatant volume

\section{Results and Discussion}

\subsection{Results}

Based on the research process carried out, protease and lipase test data can be seen in the following table. 
Table 1. The results of qualitatively from the protease activity

\begin{tabular}{cccc}
\hline No & Sample & $\begin{array}{c}\text { Time of } \\
\text { Fermentation } \\
\text { (days) }\end{array}$ & Biuret reagent \\
\hline & skim milk 1\% & 3 & Purple \\
1 & & 5 & Faded purple \\
2 & Sample 1 (Metabolite + PDB) & 9 & Faded purple \\
3 & & 13 & Faded purple \\
4 & & 3 & Faded purple \\
5 & & 5 & Faded purple \\
6 & Sample 2 $\left(\right.$ Metabolite + PDB $+_{7}$ & 9 & Faded purple \\
7 & $\left.\mathrm{KH}_{2} \mathrm{PO}_{4} 1 \%+\mathrm{MgSO}_{4} 0,5 \%\right)$ & 13 & Faded purple \\
8 & & 3 & Faded purple \\
9 & & 5 & Faded purple \\
10 & $\mathrm{Sample} 3\left(\mathrm{Metabolite}+\mathrm{PDB}+_{11}\right.$ & 9 & Faded purple \\
12 & $\left.\mathrm{KH}_{2} \mathrm{PO}_{4} 1,5 \%+\mathrm{MgSO}_{4} 0,5 \%\right)$ & 13 & Faded purple \\
13 & & 3 & Faded purple \\
14 & $\mathrm{Sample} 4\left(\mathrm{Metabolite}+\mathrm{PDB}+_{15}\right.$ & 5 & Faded purple \\
16 & $\left.\mathrm{KH}_{2} \mathrm{PO}_{4} 2 \%+\mathrm{MgSO}_{4} 0,5 \%\right)$ & 9 & Faded purple \\
& & 13 & Faded purple \\
\hline
\end{tabular}

Semi-quantitative testing of the protease index uses a test substrate in the form of Potato Dextrose Agar (PDA), which has been added with 1\% skim milk. The results of the index of protease showed in Figure 1. The protease activity's quantitative testing carried out using the Kunitz chemical method with a UV-vis spectrophotometer and casein as the substrate shown in Figure 2. The semi-quantitative testing of lipase use PDA media that has been added methyl red, tween, and olive oil showed in Figure 3. The results quantitative of the lipase activity showed in Figure 4.

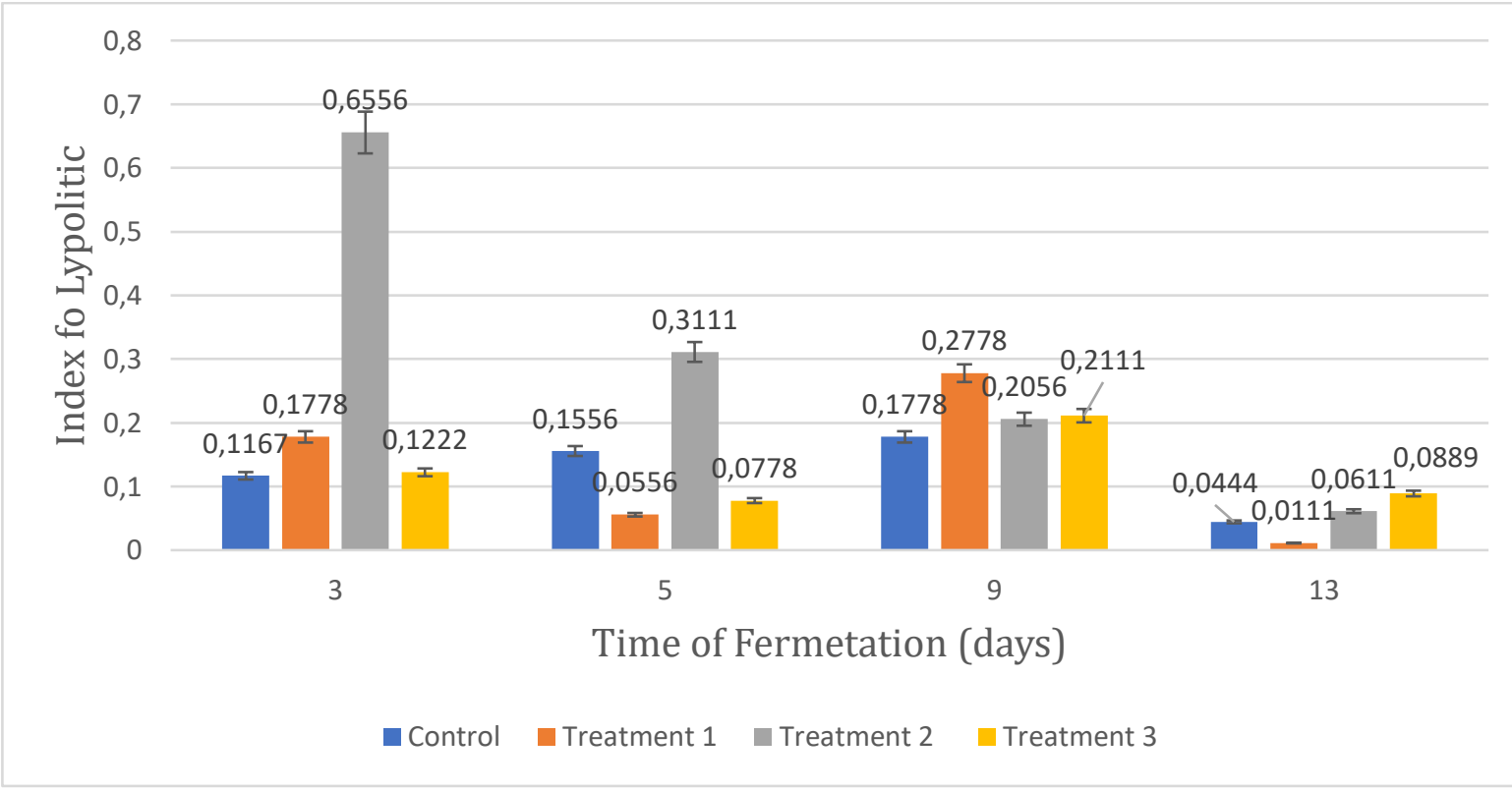

Figure 1. The results of the index of protease 


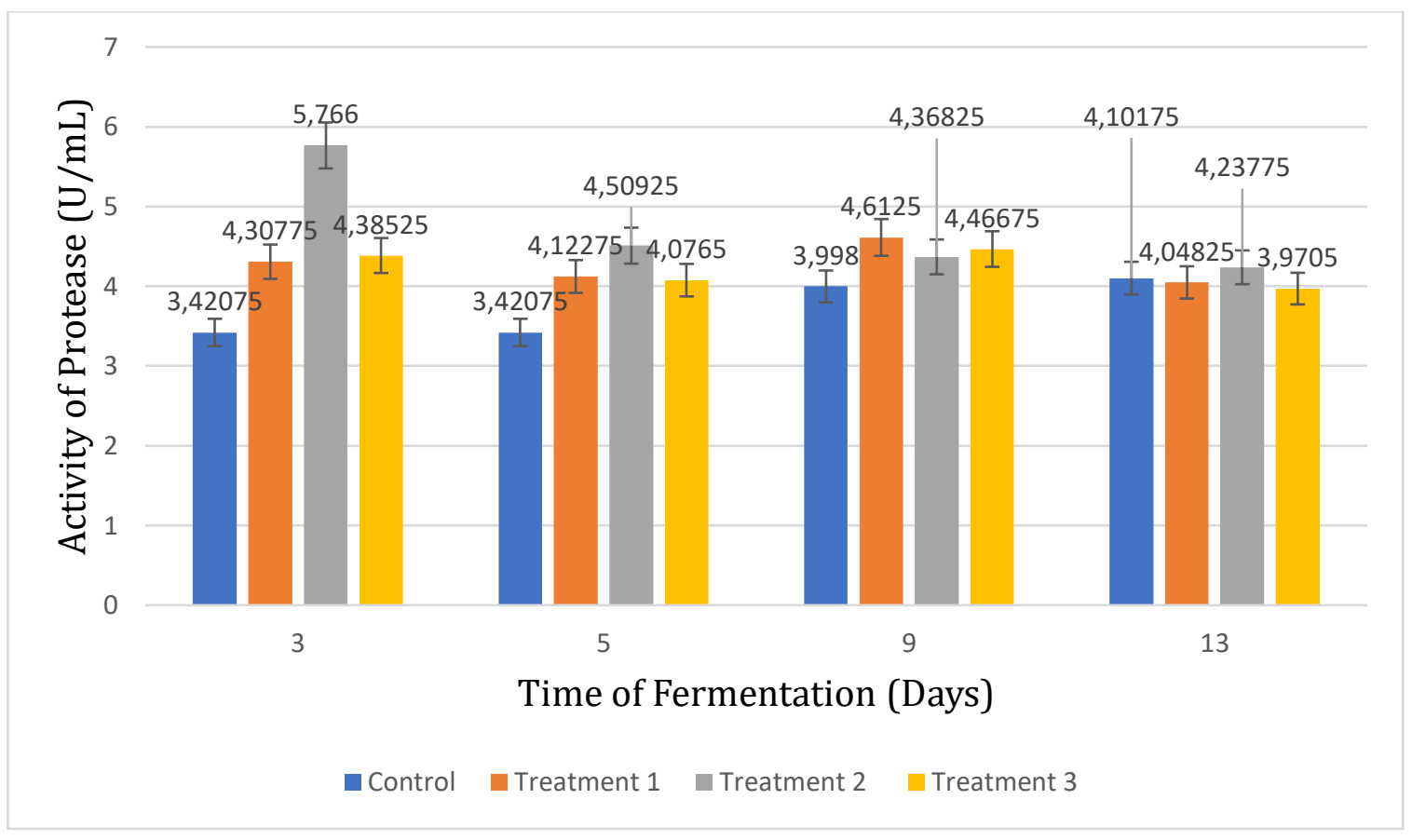

Figure 2. The results of the protease activity

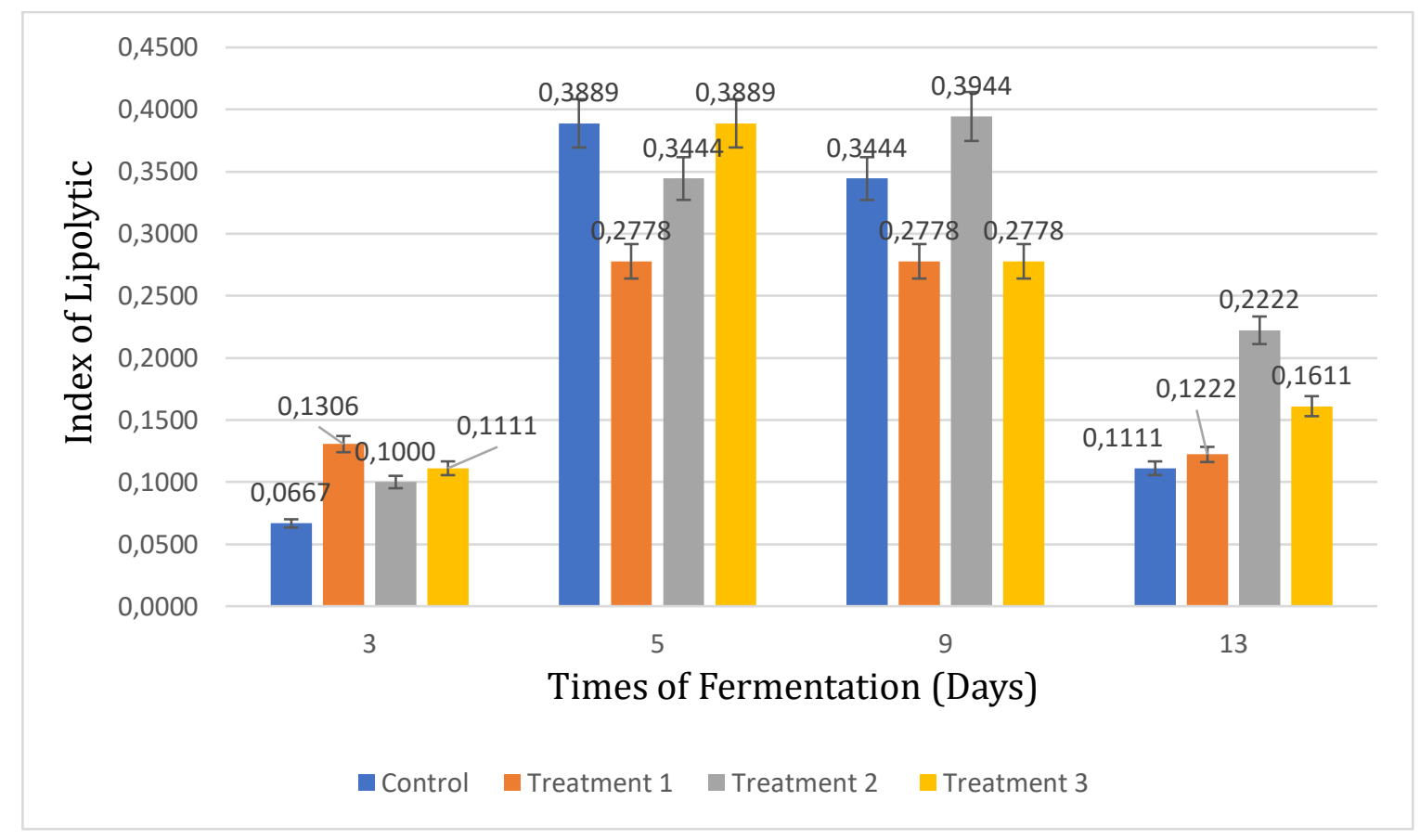

Figure 3. The results of index lipolytic 


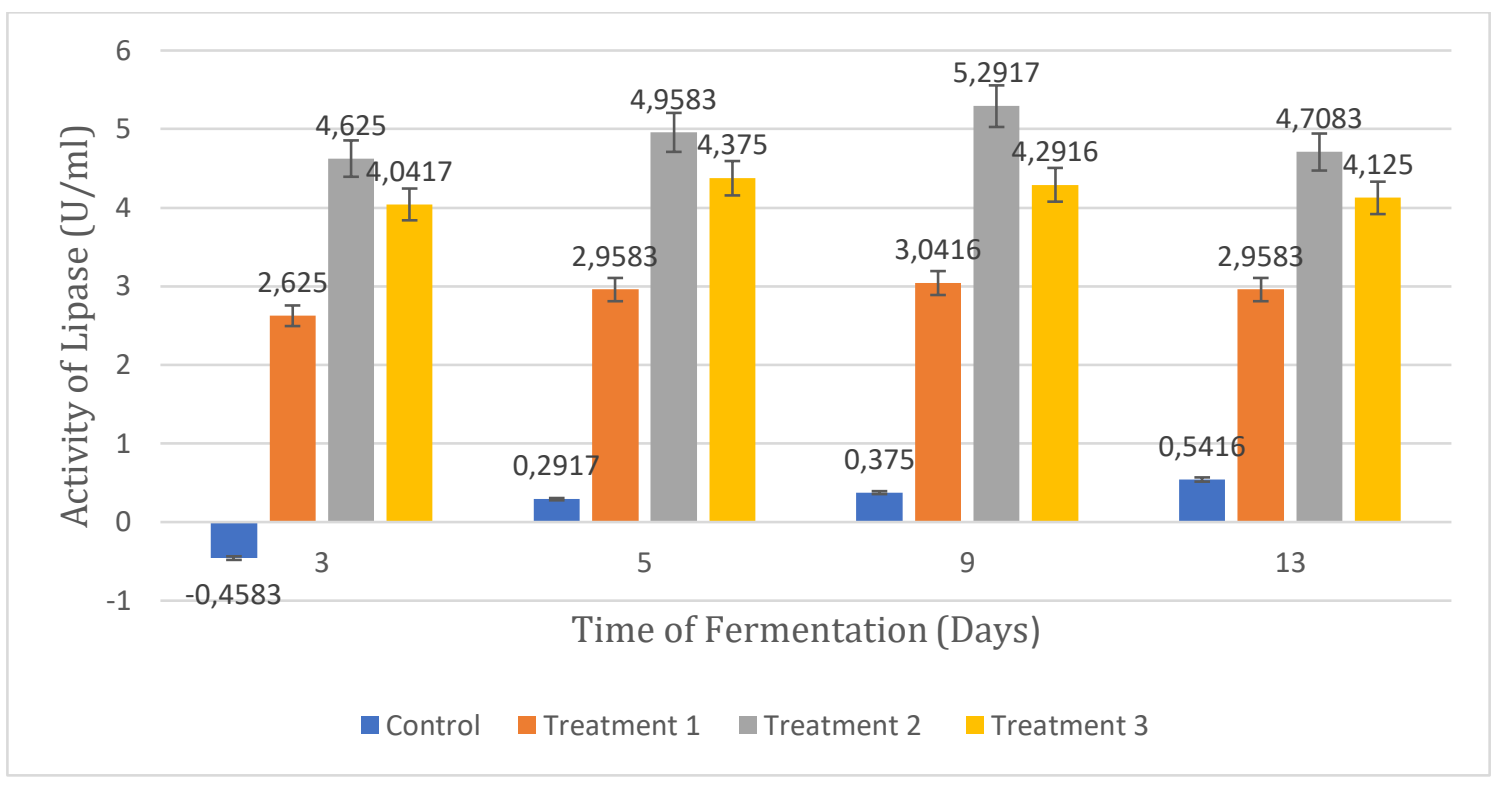

Figure 4. The results of lipase activity

\subsection{Discussion}

The fermentation process is influenced by internal factors (enzymes) and external cells (environment, temperature, $\mathrm{pH}$, agitation, aeration). Then the composition of the fermentation media will significantly affect the cell. The piece of the fermentation substrate used includes mineral salts and glucose. Potato Dextrose Broth (PDB) is glucose used for carbon sources, increasing bioactive metabolites' production. The mineral salts used are $\mathrm{KH}_{2} \mathrm{PO}_{4}$ and $\mathrm{MgSO}_{4} .7 \mathrm{H}_{2} \mathrm{O}$. Some metals and minerals can affect the process of cell growth and fermentation. One is magnesium, and magnesium ions can affect yeast cells' development and growth and fermentative respiration metabolism. The addition of nutrients with different concentrations in this study was $\mathrm{KH}_{2} \mathrm{PO}_{4}$. The best enzyme testing results were obtained in sample 3 , which contained $\mathrm{PDB}+1.5 \% \mathrm{KH}_{2} \mathrm{PO}_{4}+0.5 \% \mathrm{MgSO}$. It is because the $\mathrm{KH}_{2} \mathrm{PO}_{4}$ mineral salt is used as a phosphate source. In fermentation, phosphate has an essential function because it plays a role in enzyme production and cell growth. The use of $\mathrm{KH}_{2} \mathrm{PO}_{4}$ above the optimum limit or high concentrations can inhibit cell growth and enzyme stability by increasing the medium's alkalinity (Carrazco-Palafox et al., 2018; Kalayu, 2019; Sun et al., 2015).

Previous research conducted by Soeka and Suliastini was isolating microbes from nature to produce proteases by fermentation with growth media without inducers. The protease activity was $315.88 \mathrm{U} / \mathrm{mL}$, with a two-day fermentation time (Poernomo et al., 2017; Soeka \& Sulistiani, 2017). The enzyme activities were tested using the supernatant metabolites of Candida tropicalis isolates, namely protease and lipase enzymes. Candida tropicalis isolate metabolites were observed in the presence of protease enzymes qualitatively, semiquantitatively, and quantitatively. Qualitative testing is done by the 
biuret test. The test results showed in table 1 . The test's principle is to detect the presence of peptide bonds obtained by the reaction in the form of purple color in the solution that indicates protein presence. It happens because the $\mathrm{Cu}^{2+}$ ion (from the Biuret reagent) in an alkaline atmosphere reacts with polypeptides or peptide bonds that make up the protein to form a purple complex (violet) (Putri et al., 2016). The material used as an opposing substrate and comparison is $1 \%$ skim milk. The existence of a fading purple or blue color can be said to be a negative biuret test, which shows the presence of peptide bonds by the protease enzyme. The results of the biuret test for Candida tropicalis isolates are in Table 1 . The results show a paler or fading purple color. It means that the metabolite isolate of Candida tropicalis produces a prosthetic enzyme.

Semi-quantitative testing uses a test substrate in Potato Dextrose Agar (PDA), added with $1 \%$ skim milk. Observations were made by looking at the clear zone produced. The results of this test showed in Figure 1. The results showed that a clear area formed on the test substrate. Candida tropicalis isolate metabolites containing the highest protease enzyme were obtained three days after fermentation of $\mathrm{T} 2\left(\mathrm{PDB}+\mathrm{KH}_{2} \mathrm{PO}_{4} 1.5 \%+\mathrm{MgSO}_{4}\right.$ $0.5 \%)$. The test results based on the same fermentation time showed that on day 3 , the proteolytic index value of treatments 1 and 3 was more significant than the control $(\mathrm{p}$ $<0.05)$. The proteolytic index on day 5 showed that the group given treatment three was more significant than the control $(p<0.05)$ while the group's assigned treatment 1 and 3 had a smaller proteolytic index than the control $(\mathrm{p}<0.05)$. At nine days of fermentation, the groups were given treatment 1,2 , and 3 had a higher proteolytic index than the control ( $p<0.05$ ). At 13 days of fermentation, the groups given treatment 1,2 , and 3 had lower proteolytic indexes than the control $(\mathrm{p}<0.05)$. In this study, the highest proteolytic index of the control group was at the fermentation time of 9 days, in the treatment group 1 at nine days of incubation, the administration of treatment 2 with a fermentation time of 3 days, and the provision of treatment 3 with a fermentation time of 9 days. Based on these results, giving treatment 2 with a fermentation time of 3 days was the group that gave the best proteolytic index value $(0,6556 \pm 0,0090) \mathrm{U} / \mathrm{mL}$ among all treatment groups. The clear zone is caused by the activity of extracellular proteolytic enzymes produced by Candida tropicalis in hydrolyzing casein that is in skim milk on the media. The clear area is an indicator that isolates can utilize protein in the media as a nutritional source. The protease index produced by Candida tropicalis is smaller compared to the protease index produced by isolates from tofu wastewater (Asril \& Leksikowati, 2019).

Quantitative testing carried out using the Kunitz chemical method with a UV-vis spectrophotometer and casein as the substrate. The results of this test showed in Figure 2. This method begins with the incubation of isolate metabolites in the substrate. Enzyme activity after incubation stopped with trichloroacetic acid (TCA) solution. The enzyme activity then measured the upper at $280 \mathrm{~nm}$ wavelength to determine the tyrosine amount formed from the hydrolysis of casein dissolved in TCA. One unit of enzyme is defined as an increase in 0.1 uptakes of TCA containing casein (Sumardi et al., 2019). Based on protease activity testing results, giving treatment two compared to the control $(p<0.05)$ 
with a fermentation time of 3 days was the group that gave the best protease activity value among all treatment groups. The results showed that the metabolite isolate of Candida tropicalis after three days fermentation in $\mathrm{T} 2$ (PDB $+\mathrm{KH}_{2} \mathrm{PO}_{4} 1.5 \%+\mathrm{MgSO}_{4} 0.5 \%$ ) had the highest activity, amounting to $5,776 \pm 0,495 \mathrm{U} / \mathrm{mL}$. It is the need for added nutrients that have been fulfilled (Yuniarti et al., 2015). Based on the results of research that Candida tropicalis isolated from soil has protease activity. As in research conducted by Nizar microbial isolates from the mangrove, forest soils have a 1.9 x 10-4 U / mL (Nizar et al., 2015). The results of the protease enzyme activity test of Candida tropicalis isolates semiquantitatively and quantitatively showed the presence of protease enzyme activity on fermentation for three days. It is because three days of fermentation is an exponential phase where the metabolites produced are very high.

Microbes that can produce lipases are considered very important for several applications because they can be faster in finding natural sources of new lipases (Javed et al., 2018). Testing the existence of lipase enzymes is done semiquantitatively and quantitatively. Semi-quantitative testing uses PDA media that has been added methyl red, tween, and olive oil. The principle is to identify the presence of clear zones when isolate metabolites are incubated in the substrate, then the lipolytic index is calculated. Metabolite test results showed that the highest lipase enzyme activity produced by sample 3. The metabolite was obtained after 9 days fermentation in $\mathrm{T} 2\left(\mathrm{PDB}+\mathrm{KH}_{2} \mathrm{PO}_{4} 1.5 \%+\right.$ $\mathrm{MgSO}_{4}$ 0.5\%). The results showed in Figure 3. Based on these results, giving treatment 2 with a fermentation time of 9 days was the group that gave the best lipolytic index value $(0,394 \pm 0,053) \mathrm{U} / \mathrm{mL}$ among all treatment groups. The result is a clear zone around the bacterial colony after incubation and a change in the media's color to bright yellow. It means that Candida tropicalis isolate metabolites can hydrolyze fats into glycerol and fatty acids soluble in the media.

Quantitative lipase activity testing carried out using the acidimetry titration method with sodium hydroxide $(\mathrm{NaOH})$ as a titrant, olive oil as a substrate, and phenolphthalein (PP) indicator as an indicator. The results showed in Figure 4. The appearance of changes indicates the existence of lipase enzyme activity in the solution from the original colorless to pink due to $\mathrm{pH}$ changes. The pink color appears when $\mathrm{NaOH}$ can no longer bind to fatty acids, thereby giving alkaline properties in the solution and giving rise to a pink color (Stoytcheva et al., 2012). The volume of $\mathrm{NaOH}$ obtained was then calculated by the activity value of the lipase enzyme. The isolate metabolites produced the highest lipase enzyme after nine days of fermentation of T2 (PDB $+\mathrm{KH}_{2} \mathrm{PO}_{4} 1.5 \%+\mathrm{MgSO} 4$ $0.5 \%$ ) in the amount of $5.2917 \pm 0,0167 \mathrm{U} / \mathrm{mL}$. The high volume of $\mathrm{NaOH}$ needed indicates the more significant fatty acids produced from the lipid hydrolysis process. The results showed that Candida tropicalis could produce lipase. It is also found that another type of Candida, Candida Antarctica, and Candida parapsilosis, also has lipase (Ribas et al., 2019; Monteiro et al., 2020). 


\section{Conclusion}

Based on these results, the Candida tropicalis metabolite giving the best proteolytic index value $(0,6556 \pm 0,0090) \mathrm{U} / \mathrm{mL}$. The results showed that the metabolite isolate of Candida tropicalis had the highest activity, amounting to $5,776 \pm 0,495 \mathrm{U} / \mathrm{mL}$. The best results of lipolytic index value $(0,394 \pm 0,053) \mathrm{U} / \mathrm{mL}$. The Candida tropicalis metabolites produced the highest lipase enzyme after nine days of fermentation in $5.2917 \pm 0,0167$ $\mathrm{U} / \mathrm{mL}$.

\section{Acknowledgments}

Thank you to LPPM UNJANI for providing funding for this research.

\section{References}

A, J., M, P., \& B, T. (2017). Production and Optimization of Lipase Enzyme from Mesophiles and Thermophiles. Journal of Microbial \& Biochemical Technology, 09(03), 126-131. https://doi.org/10.4172/1948-5948.1000355

Asril, M., \& Leksikowati, S. S. (2019). Isolasi dan Seleksi Bakteri Proteolitik Asal Limbah Cair Tahu Sebagai Dasar Penentuan Agen Pembuatan Biofertilizer. Elkawnie, 5(2), 86. https://doi.org/10.22373/ekw.v5i2.4356

Bestari, N. C., \& Suharjono. (2015). Uji Kualitatif dan Kuantitatif Isolat Bakteri Lipolitik dari Limbah Cair Pabrik. Jurnal Biotropika, 3(3), 151-155.

Bharathi, D., Rajalakshmi, G., \& Komathi, S. (2019). Optimization and Production of Lipase Enzyme from Bacterial Strains Isolated from Petrol Spilled Soil. Journal of King Saud University - Science, 31(4), 898-901. https://doi.org/10.1016/j.jksus.2017.12.018

Câmara Ribas, R. K. da, dos Santos Carboni, D., Cazarolli, J. C., Flôres, S. H., RamirezCastrillon, M., \& Valente, P. (2019). Nitrogen Source and pH Interact and Modulate Lipase Secretion in a Non-Clinical Strain of Candida parapsilosis. Acta Scientiarum Biological Sciences, 41(1), 1-12. https://doi.org/10.4025/actascibiolsci.v41i1.45481

Carrazco-Palafox, J., Rivera-Chavira, B. E., Ramírez-Baca, N., Manzanares-Papayanopoulos, L. I., \& Nevárez-Moorillón, G. V. (2018). Improved Method for Qualitative Screening of Lipolytic Bacterial Strains. MethodsX, 5, 68-74. https://doi.org/10.1016/ j.mex.2018.01.004

Gupta, R., Kumari, A., Syal, P., \& Singh, Y. (2015). Molecular and Functional Diversity Of Yeast and Fungal Lipases: Their Role in Biotechnology and Cellular Physiology. Progress in Lipid Research. https://doi.org/10.1016/j.plipres.2014.12.001

Duanis-Assaf, D., Kenan, E., Sionov, R., Steinberg, D., \& Shemesh, M. (2020). Proteolytic Activity of Bacillus subtilis upon k-Casein Undermines Its "Caries-Safe" Effect. Microorganisms, 8(2), 1-12. https://doi.org/10.3390/microorganisms8020221 
Hermansyah, Novia, \& Wiraningsih, M. (2016). Bioethanol Production From Cellulose by Candida tropicalis, as an Alternative Microbial Agent to Produce Ethanol from Lignocellulosic Biomass. Sriwijaya Journal of Environment, 1(1), 10-13. https://doi.org/10.22135/sje.2016.1.1.10-13

Javed, S., Azeem, F., Hussain, S., Rasul, I., Siddique, M. H., Riaz, M., Afzal, M., Kouser, A., \& Nadeem, H. (2018). Bacterial lipases: A Review on Purification and Characterization. Progress in Biophysics and Molecular Biology, 132, 23-34. https://doi.org/10.1016/j.pbiomolbio.2017.07.014

Kalayu, G. (2019). Phosphate solubilizing microorganisms: Promising Approach as Biofertilizers. In International Journal of Agronomy, 2019, 1-7. https://doi.org/10.1155/2019/4917256

Liu, Y., \& Chen, J. Y. (2016). Enzyme Immobilization on Cellulose Matrixes. Journal of Bioactive and Compatible Polymers, 31(6), 553-567. https://doi.org/10.1177/ 0883911516637377

Liu, Z., \& Pan, J. (2017). A Practical Method for Extending the Biuret Assay to Protein Determination of Corn-Based Products. Food Chemistry, 224(June), 289-293. https://doi.org/10.1016/j.foodchem.2016.12.084

Mahyati, M. (2017). Uji Daya Hambat Senyawa Xylitol dari Limbah Tongkol Jagung pada Bakteri Streptococcus mutans. INTEK: Jurnal Penelitian, 4(2), 111. https://doi.org/10.31963/intek.v4i2.153

Monteiro, R. R. C., Virgen-Ortiz, J. J., Berenguer-Murcia, Á., da Rocha, T. N., dos Santos, J. C. S., Alcántara, A. R., \& Fernandez-Lafuente, R. (2020). Biotechnological Relevance of the Lipase A from Candida antarctica. Catalysis Today, November 2019, 1-14. https://doi.org/10.1016/j.cattod.2020.03.026

Stoytcheva, M., Montero, G., Zlatev, R., A. Leon, J., \& Gochev, V. (2012). Analytical Methods for Lipases Activity Determination: A Review. Current Analytical Chemistry, 8(3), 400-407. https://doi.org/10.2174/157341112801264879

Nizar, I., Wirajana, I., \& Laksmiwati, A. (2015). Analisis Potensi Protease Ektraseluler Tanah Hutan Mangrove Pantai Suwung Kauh Bali. Cakra Kimia (Indonesian E-Journal of Applied Chemistry).

Oktavia, Y., Lestari, S. D., Lestari, S., Herpandi, ., \& Jannah, M. (2018). Optimasi Waktu Inkubasi Produksi Protease dan Amilase Isolat Bakteri Asal Terasi Ikan Teri Stolephorus sp. Jurnal Ilmu Dan Teknologi Kelautan Tropis, 10(3), 719-725. https://doi.org/10.29244/jitkt.v10i3.18840

Ozturkoglu-Budak, S., Wiebenga, A., Bron, P. A., \& de Vries, R. P. (2016). Protease and Lipase Activities of Fungal and Bacterial Strains Derived from an Artisanal Raw Ewe's Milk Cheese. International Journal of Food Microbiology. https://doi.org/10.1016/j.ijfoodmicro.2016.08.007 
Pandey, N., Gupta, M. K., \& Tilak, R. (2018). Extracellular Hydrolytic Enzyme Activities of The Different Candida spp. Isolated from The Blood of The Intensive Care UnitAdmitted Patients. Journal of Laboratory Physicians. https://doi.org/10.4103/jlp.jlp_81_18

Poernomo, A. T., Isnaeni, Sugianto, Purwanto, D. A., Dewi, A. C., \& Suryagama, D. (2017). Pengaruh Nutrisi pada Produksi dan Karakterisasi Protease dari Bakteri Termofilik Isolat LS-1 Lumpur Sidoarjo. Farmasi Dan Ilmu Kefarmasian Indonesia, 4(2), 51-58. http://dx.doi.org/10.20473/jfiki.v4i22017.51-58

Putri, A. A. B., Yuliet, Y., \& Jamaluddin, J. (2016). Analisis Kadar Albumin Ikan Sidat (Anguilla marmorata dan Anguilla bicolor) dan Uji Aktivitas Penyembuhan Luka Terbuka Pada Kelinci (Oryctolagus cuniculus). Jurnal Farmasi Galenika (Galenika Journal of Pharmacy), 2(2), 90-95. https://doi.org/10.22487/ j24428744.2016.v2.i2.5967

Ramnath, L., Sithole, B., \& Govinden, R. (2017). Identification of Lipolytic Enzymes Isolated from Bacteria Indigenous to Eucalyptus Wood Species for Application in The Pulping Industry. Biotechnology Reports, 15(April), 114-124. https://doi.org/10.1016/j.btre.2017.07.004

Soeka, Y. S., \& Sulistiani, S. (2017). Karakterisasi Enzim Protease dari Bakteri Stenotrophomonas sp. Asal Gunung Bromo, Jawa Timur. Berita Biologi, 16(2). https://doi.org/10.14203/beritabiologi.v16i2.2940

Subagiyo, S., Djarod, M. S. R., \& Setyati, W. A. (2017). Potensi Ekosistem Mangrove sebagai Sumber Bakteri Untuk Produksi Protease, Amilase dan Selulase. Jurnal Kelautan Tropis, 20(2), 106. https://doi.org/10.14710/jkt.v20i2.1703

Sumardi, S., Farisi, S., Ekowati, C. N., \& Diana, M. S. (2019). Aktivitas dan Karakterisasi Enzim Protease Isolat Bacillus sp. (UJ132) Secara Kualitatif dan Kuantitatif. Jurnal Riset Akuakultur, 14(3), 193-199. https://doi.org/10.15578/jra.14.3.2019.193-199

Sun, X. Y., Zhao, Y., Liu, L. L., Jia, B., Zhao, F., Huang, W. D., \& Zhan, J. (2015). Copper Tolerance and Biosorption of Saccharomyces Cerevisiae During Alcoholic $\begin{array}{llll}\text { Fermentation. PLoS ONE, 10(6), } & \text { 18. }\end{array}$ https://doi.org/10.1371/journal.pone.0128611

Weerasekera, M. M., Wijesinghe, G. K., Jayarathna, T. A., Gunasekara, C. P., Fernando, N., Kottegoda, N., \& Samaranayake, L. P. (2016). Culture Media Profoundly Affect Candida Albicans and Candida tropicalis Growth, Adhesion, and Biofilm Development. Memorias Do Instituto Oswaldo Cruz, 111(11), 697-702. https://doi.org/10.1590/0074-02760160294 
Yuniarti, R., Nugroho, T. T., \& Puspita, F. (2015). Uji Aktivitas Enzim Protease dari Isolat Bacillus sp. Galur Lokal Riau. Jom Fmipa. https://jom.unri.ac.id/index.php/ JOMFMIPA/article/view/4378

Zuza-Alves, D. L., Silva-Rocha, W. P., \& Chaves, G. M. (2017). An Update on Candida Tropicalis Based on Basic and Clinical Approaches. In Frontiers in Microbiology. https://doi.org/10.3389/fmicb.2017.01927 